American Journal of Applied Sciences 8 (2): 182-185, 2011

ISSN 1546-9239

(C) 2010 Science Publications

\title{
Arsenic, Nickel and Iron Concentration levels in Water Samples from Hand-Dug Wells from Ugbe Akoko
}

\author{
O.M. Afolabi, I.R. Ajayi, R.S. Fayose, O. Olubosede and A.G. Sunday \\ Department of Physics and Electronics, \\ Adekunle Ajasin University, Akungba Akoko, Ondo state, Nigeria
}

\begin{abstract}
Problem statement: The concentration of Arsenic, Nickel and Iron from twenty water samples from Ugbe Akoko in Ondo state, Nigeria was determined with atomic absorption spectrometer and conductivity meter. Approach: The aims are to determine the level of concentration of the three heavy metals in the well water, the relationship between the WHO reference standard for pure water and the well water sample and the potential hazards in utilizing the water for their sole purposes of drinking and cooking. Results: The result showed that, water samples 2, 6 8, 14, 17, 18 and 19 have low level of Arsenic metal pollution with values below $0.05 \mathrm{ppm}$ WHO standard. Samples 1, 4, 6, 8, $10,13,14$ and 19 are with low level Nickel concentrations compare to WHO acceptable value of 0.02 . The Fe occurrence in samples 1, 4, 5, 6, 7, 8, 9, 10, 11, 12, 14, 15, 16, 17, 18, 19 and 20 is below the WHO standard permissible level. Only water samples 2, 3 and 13 have higher Fe value (2-13 times) above WHO acceptable level. Water samples 6, 8, 14 and 19 have values of As, Ni and Fe below the WHO acceptable standard. Conclusion/Recommendations: However the conductivity result which is too high shows that other metals or salts can still be present. The As, Ni and Fe pollution result from human activities involving improper refuse and sewage disposal often at places with shallow well resulting from sediment overlying the impervious bedrock.
\end{abstract}

Key words: Water samples, hand-dug wells, iron concentration, metallic taste, Fe pollution

\section{INTRODUCTION}

Water and surface pollution accumulates after precipitation under the influence of gravity in rock cavities as a vast ground water reservoir supplying wells, boreholes, springs and flowing streams (Harr, 1962). In urban rural communities, people do not know the level of purity of water used for drinking, cooking and cleaning purposes. Ground water can be utilized by constructing dug wells or boreholes and most water utilized in communities emanate from dug wells. High level concentration of As in groundwater used for drinking have been proved to be directly detrimental to human health (Chakraborti et al., 1999). The health problems include abdominal pain, anorexia, brittle nails, diarrhea, nausea, vomiting, chronic anemia, burning in mouth/esophagus/stomach/bowel, confusion, convulsions, dermatitis, drowsiness, enzyme inhibition, garlicky odor to breath/stool, hair loss, headaches, hyper-pigmentation of nails and skin, increased risk of liver/lung/skin cancers, low grade fever, mucous in nose and throat, muscle aches/spasms/weakness, nervousness, respiratory tract infection, swallowing difficulty, sweet metallic taste, throat constriction. The health problems resulting from high level of concentration of Nickel in human include anorexia, kidney dysfunction, apathy, disruption of hormone and lipid metabolism, fever, hemorrhages, headache, heart attack, intestinal cancer, low blood pressure, muscle tremors, nausea, oral cancer, skin problems, vomiting while high accumulation of iron can result in amenorrhea, anger, rheumatoid arthritis, birth defects, bleeding gums, cancer, constipation, diabetes, dizziness, emotional problems, fatigue, headache, heart damage, heart failure, hepatitis, high blood pressure, hostility, hyperactivity, infections, insomnia, irritability, joint pain, liver disease, loss of weight, mental problems, metallic taste in mouth, myasthenia gravis, nausea, pancreas damage, Parkinson's disease, premature aging, schizophrenia, scurvy, shortness of breath and stubbornness (http://wwww.alternativedoctor.com; Caravati, 2004; Klaassen and Watkins, 2010; Mukherjee et al, 1999; Alshiyab et al., 2008).

Groundwater constitutes a major source of drinking water supply in many areas of crystalline basement in Africa; hence determination of groundwater quality in basement aquifers tapped with wells is significant to good human health. The aims of this research study are

Corresponding Author: O.M. Afolabi, Department of Physics and Electronics, Adekunle Ajasin University, Akungba Akoko, Ondo state, Nigeria 
to measure the three heavy metal (As, $\mathrm{Ni}$ and $\mathrm{Fe}$ ) concentration with alpha 4 series atomic absorption spectrometer model PG990 serial no 150990010317 at Obafemi Awolowo University, to check the concentrations with WHO standard on allowed concentration, to enumerate the wells that are potentially hazardous to human if used for drinking or cooking, to check with the human activities at the area the level of environmental pollution. High concentrations of iron may be expected in groundwater from areas of crystalline basement if acidic conditions occur. As groundwater abstracted from the crystalline basement is often derived from dug wells, high iron concentrations in these may be due to the presence of particulate iron, especially if the groundwater is highly turbid. Alagbe (2002) found some high-iron groundwater in basement rocks of north central Nigeria, although all were found to be below the WHO guideline value. High concentration levels of metals are useful tracers of environmental pollution (Manta et al., 2002). The composition of natural drainage and aerial extent are a function of the mineralogy, geochemistry, depositional characteristics of the deposit and of climatic and hydrologic conditions at the deposit site (Seal and Hammarstrom, 2003; Wanty et al., 2003). The complex interaction of physical, geochemical and biological processes, including hydrologic transport, mixing and dilution, evaporation, erosion, oxidationreduction reactions, solution complication, mineral precipitation and dissolution, adsorption and biological production and regeneration, determine the eventual fate of constituents released from various deposits (Paulson, 2001).

Site description: Ugbe Akoko is a city underlain by Precambrian basement complex terrain with few granite gneiss outcrops. The Quaternary sediments accumulating on the batholiths are from 0.2-7 m thick towards the west and middle of the town in the places where outcrops of granite gneiss are noticed. These area are where refuse consisting mostly rusting metal parts, pipes, tin, paper, plastic and battery containers are dumped. The elevation is $120 \mathrm{~m}$ above mean sea level at the western middle side, the topography fell lower towards the east and the sediment increased to $20 \mathrm{~m}$. The right side of the dividing Ikare-Epinmi linear road is underlain by sands and sandy silt. There are mechanic, panel beaters, welders and battery chargers shops spread on both the sides of the roads from the south to the north punctuated by Schools and retail shops and a market at the northern-eastern end of the town. Few scattered refused dumps on undeveloped lands following thickly dwelled neighborhood have
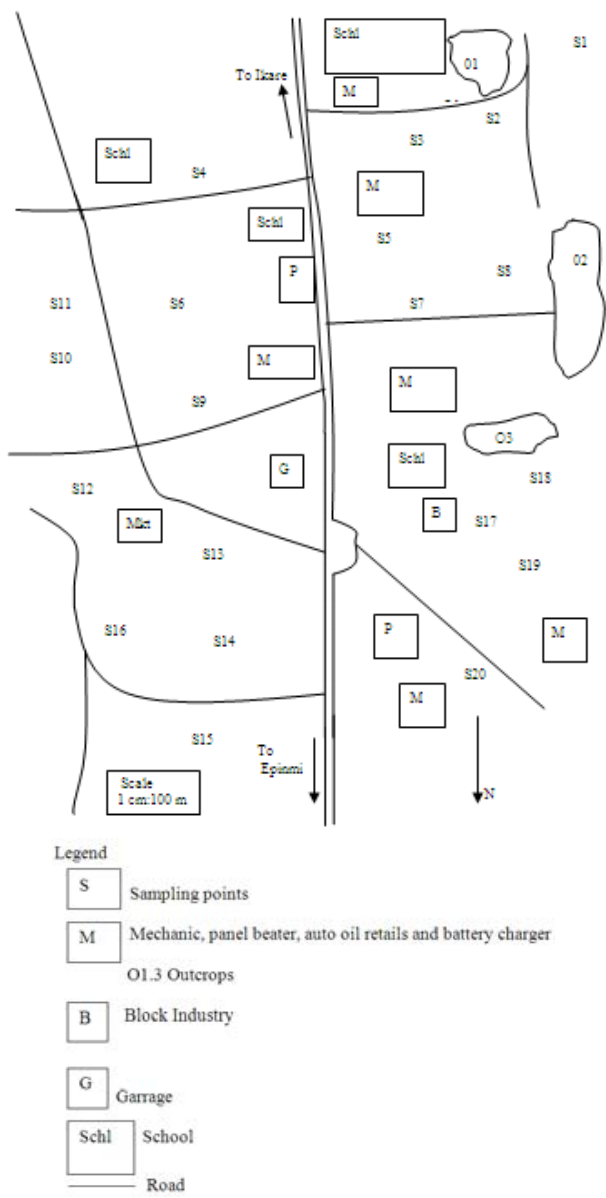

Fig. 1: Ugbe Community showing places of sample collection for AAS metal concentration measurement

high accumulations of iron plates, pipes, cooking wares, rusting automobile parts, old containers of nylon, plastic and papers, of which light ones are blown away to residential area during wind preceding heavy rain. Some sparse spread of granite gneiss outcrops are visible towards the left northern side of the town where the elevation dropped to $90 \mathrm{~m}$ below mean sea level. On the eastern side there are few seasonal rivers discharging into river dada that is flowing from Ese Ikare towards Eastern end of Arigidi Akoko, both settlements are interwoven boundary to the west of Ugbe town. The Eastern side of Ugbe slope gently with increasing Quaternary sediment to an elevation of $75 \mathrm{~m}$ above mean sea level to the local government of Akoko North East headquarters in Ikare. It is on the either side where the waste from the major road and mechanic and panel beating repair shops drain due to the topography. Directly southwards of the local government is a slope 
Am. J. Applied Sci., 8 (2): 182-185, 2011

upwards to Ikare town to an elevation of $115 \mathrm{~m}$. Ugbe Akoko is in the Northern part of Ondo state southwestern Nigeria within latitudes $7^{\circ} 30^{\prime}-7^{\circ} 30^{\prime} \mathrm{N}$ and longitudes $5^{\circ} 45-5^{\circ} 50^{\prime} \mathrm{E}$.

\section{MATERIALS AND METHODS}

During the dry season, $60 \mathrm{~mL}$ of twenty samples of well water were collected in polyethylene bottles between 12th-13th November 2008 from already available wells normally used by the inhabitant such that most area from Ugbe Akoko are represented see Fig. 1. The depth of water table from the wells, range from 4-20 m. Two separate aliquots were filtered through $0.2 \mu \mathrm{m}$ filters. One was acidified using $17 \%$ Aristar $\mathrm{HNO}_{3}\left(1 \% \quad \mathrm{v} \mathrm{v}^{-1}\right)$ for $\mathrm{Fe}$ and $\mathrm{Ni}$ level measurement while the second was acidified using concentrated Aristar $\mathrm{HCl}\left(1 \% \mathrm{v} \mathrm{v}^{-1}\right)$ for total As concentration determination (McCleskey et al., 2004; Smedley et al., 2007) with alpha 4 series atomic absorption spectrometer model PG990 serial no 150990010317 at Obafemi Awolowo University for As, $\mathrm{Ni}$ and Fe. Electrical conductivity was also determined with the mettler Toledo (MC 126) conductivity meter.

\section{RESULTS}

The data from AAS measurements and Conductivity data emanating from 20 samples of water from Ugbe Akoko are shown in Table 1.

The AAS data in Table 1 shows that water samples 2, 6, 8, 14, 17, 18 and 19 have low level of Arsenic metal pollution with values below $0.05 \mathrm{ppm}$ WHO standard (WHO, 2004). Samples 1, 4, 6, 8, 10, 13, 14 and 19 are with low level Nickel concentrations compare to WHO acceptable value of 0.02 . The Fe occurrence in samples $1,4,5,6,7,8,9,10,11,1214$, $1516,1718,19$ and 20 is below the WHO standard permissible level. At the time of measurement, water samples 6, 8, 14 and 19 have values of as, $\mathrm{Ni}$ and $\mathrm{Fe}$ below the WHO acceptable standard. Only water samples 2, 3 and 13 have higher Fe value (2-13 times) above WHO acceptable level.

\section{DISCUSSION}

The reason for the few samples of water with iron concentration values above WHO standard can be due to people collecting particulate iron and other metals (aluminum and copper) to companies for recycling into other metal products. The rusted or corroded metals leach into soil and are drained through thin sediment
Table 1: Elements' concentration and comparison with WHO standard

\begin{tabular}{lllll}
\hline & & & \\
Water sample and & & & \\
WHO standard & As & $\mathrm{Ni}$ & $\mathrm{Fe}$ & $\mu \mathrm{S} \mathrm{cm}^{-2}$ \\
\hline 1 & 3.700 & 0.000 & 0.000 & 136.10 \\
2 & 0.000 & 0.200 & 5.700 & 805.00 \\
3 & 0.300 & 0.700 & 3.900 & 376.00 \\
4 & 0.500 & 0.000 & 0.000 & 604.00 \\
5 & 0.900 & 0.100 & 0.000 & 338.00 \\
6 & 0.000 & 0.000 & 0.000 & 409.00 \\
7 & 0.500 & 0.100 & 0.100 & 329.00 \\
8 & 0.000 & 0.000 & 0.000 & 158.30 \\
9 & 1.500 & 0.100 & 0.000 & 311.00 \\
10 & 0.900 & 0.000 & 0.000 & 315.00 \\
11 & 0.800 & 0.000 & 0.000 & 258.00 \\
12 & 0.700 & 0.100 & 0.000 & 512.00 \\
13 & 0.600 & 0.000 & 2.700 & 466.00 \\
14 & 0.000 & 0.000 & 0.000 & 513.00 \\
15 & 0.400 & 0.700 & 1.000 & 527.00 \\
16 & 0.100 & 0.800 & 0.000 & 446.00 \\
17 & 0.000 & 0.700 & 0.000 & 517.00 \\
18 & 0.000 & 0.300 & 0.000 & 377.00 \\
19 & 0.000 & 0.000 & 0.000 & 274.00 \\
20 & 0.500 & 0.200 & 0.400 & 290.00 \\
WHO standard & 0.050 & 0.020 & 1.000 & 1.00 \\
\hline & & & &
\end{tabular}

into well. Some in dust are dispersed during heavy wind preceding rain. The values of conductivity in all the samples show that more constituent metal or salt in the well water that are not yet analyzed are responsible for the very high conductivity data.

\section{CONCLUSION}

The sources of As, Ni and Fe pollution in the well water could be from the mechanic and panel beaters workshops. Human activities like washing and unprotected leakage of sewage through sediment or fault into shallow aquifer also contributed to the groundwater pollution. Proper refuse and sewage disposal and recycling system should be practiced for urban safety and development. The contribution of the rock to the element constituents in the well water should also be studied further with other analytical techniques.

\section{REFRENCES}

Alagbe, S., 2002. Groundwater resources of river KAN GIMI basin, north-central, Nigeria. Environ. Geol., 42: 404-413. DOI: 10.1007/s00254-002-0544-9

Alshiyab, H., M.S. Kalil, A.A. Hamid and W.M.W. Yusoff, 2008. Trace metal effect on hydrogen production using c.acetobutylicum. OnLine J. Biol. Sci., 8: 1-9. DOI: 10.3844/ojbsci.2008.1.9

Caravati, M. E., 2004. Arsenic and arsine gas. In: Medical Toxicology, Dart, R..C. (Ed.). Lippincott Williams and Wilkins, Philadelphia, PA, pp: 1393-1401. 
Chakraborti, D., B.K. Biswas, T.R. Chowdhury, G.K. Basu and B.K. Mamdal, 1999. Arsenic groundwater contamination and sufferings of people in Rajnandgaon district, Madhya Pradesh, India. Curr. Sci. 77, 502-504.

Harr, M.E., 1962. Groundwater and Seepage. 1st Edn, McGraw Hill Book Co. New York, ISBN 0-48666881-9, pp: 315 .

Klaassen, C.D. and J.B. Watkins, 2010. Casarett and Doull's Essentials of Toxicology. 2nd Edn., McGraw-Hill, NY, ISBN-10: 0071622403, pp: 472.

Manta, D.S., M. Angelone, A. Bellanca, R. Neri, M. Sprovieria, 2002. Heavy metals in urban soils: A case study from the city of Palermo (Sicily), Italy. Sci. Total Environ., 300: 229-243. DOI: 10.1016/S0048-9697(02)00273-5 PMID: 12685485

McCleskey, R.B., D.K. Nordstrom and A.S. Maest, 2004. Preservation of water samples for arsenic (III/V) determinations: An evaluation of the literature and new analytical results. Applied Geochem., 19: 995-1009. DOI: 10.1016/j.apgeochem.2004.01.003

Paulson, A.J., 2001. Biogeochemical removal of $\mathrm{Zn}$ and $\mathrm{Cd}$ in the coeur d'Alene river (Idaho, USA), downstream of a mining district. Sci. Total Environ., 278: 31-44. PMID: 11669275 DOI: 10.1016/S0048-9697(00)00886-X
Seal, R.R. and J.M. Hammarstrom, 2003. Geoenvironmental Models of Mineral Deposits: Example from Massive Sulfide and Gold Deposits. In: Environmental Aspects of Mine Wastes. Jambor, J.L., Blowes, D.W. and Ritchie, A.I.M. (Eds.). Mineralogical Association of Canada, Canada, pp: 11-50.

Smedley, P.L., J. Knudsen and D. Maiga 2007. Arsenic in groundwater from mineralized Proterozoic basement rocks of Burkina Faso. Applied Geochem., 22: 1072-1092.

Wanty, R.B., B.R. Berger, G.S. Plumlee and T.V.V. King, 2003. Geoenvironmental Models. In: Deposit and Geoenvironmental Models for Resource Exploitation and Environmental Security. Fabbri, A.G., Gaal, G. and McCammon, R.B. (Eds.). Kluwer Academic Publishers, Dordrecht, pp: $3-42$.

WHO, 2004. Guidelines for Drinking-water Quality. 3RD Edn., World Health Organization, Geneva, pp: 45. http://www.who.int/water_sanitation_health/dwq/G DWQ2004web.pdf 